\title{
Study of the effect of additives on biodegradation of PVC materials
}

\author{
A.K. Mazitova (D) I.N. Vikhareva* iD, A.R. Maskova iD, N.B. Gareeva iD, I.R. Shaikhullin (iD \\ Ufa State Petroleum Technological University, Ufa, Bashkortostan Republic, Russia \\ * Corresponding author: e-mail: irina.vikhareva2009@yandex.ru \\ (c) Authors, 2020
}

\begin{abstract}
Modern operating conditions of polyvinyl chloride (PVC) materials impose increased requirements for the additives used. Intensification of processing and expansion of PVC application areas, as well as providing a wide variety of its performance characteristics, are associated to a large extent with the successful solution of the problem of creating effective plasticizers. Therefore, when developing formulations of PVC plasticates, it is important to obtain and select plasticizers that meet modern high requirements for operation and environmental safety. One of the modern approaches to creating materials that can be destroyed in natural conditions is based on the use of additives that increase the ability of polymer materials to biodegrade.

This paper presents the results of developing a PVC composition with increased biodegradation. For this purpose, a mixture of plasticizers was used: dibutoxyethyl phthalate (DBOEP) with a degree of ethoxylation of 1.5 and dibutoxyethyl adipate (DBOEA) with a degree of ethoxylation of 1.5. The results of testing samples of obtained PVC compositions for biodegradation are presented. It is shown that partial replacement of a phthalate plasticizer with a non-toxic biodegradable dibutoxyethyl adipate makes it possible to obtain PVC compositions with increased biodegradation, while maintaining excellent performance properties.
\end{abstract}

KEYWORDS: adipate plasticizer, biodegradation, ecological safety, phthalate plasticizer, polyvinyl chloride.

FOR CITATION: Mazitova A.K., Vikhareva I.N., Maskova A.R., Gareeva N.B., Shaikhullin I.R. Study of the effect of additives on biodegradation of PVC materials. Nanotechnologies in Construction. 2020, Vol. 12, no. 2, pp. 94-99. DOI: 10.15828/2075-85452020-12-2-94-99.

\section{INTRODUCTION}

$\mathrm{T}$ he most industrial applications as PVC plasticizers were found in esters $[1,2]$. The volume of their production is $85 \%$ of the total release of all plasticizers $[3,4]$. Phthalates (orthophthalic acid esters) are the largest chemical group of PVC plasticizers, most of which are general-purpose [5].

Today, among the o-phthalic acid esters, the most widely used is di (2-ethylhexyl) phthalate (dioctyl phthalate, DOP), which is a standard international PVC plasticizer and is used as a standard [6-8]. The leading position of dioctyl phthalate to this day is determined primarily by the development of the production of flexible PVC - the largest consumer of DOP [9-11]. And although recently the structure of PVC consumption has noticeably changed towards hard products, nevertheless, plasticized materials based on it remain in demand in various fields.
The range of the most common plasticizers varies for different reasons: the cost of their production, environmental safety problems, increased requirements for polymer products, the creation of new materials, etc. $[12,13]$. For example, DOP, which has been used for many decades, is currently subject to restrictions in use in medical devices, children's toys, and food packaging [14-16]. The reason is that studies of the consumer properties of PVC compositions with phthalates have shown that they easily migrate from polymer compositions and are pollutants on a global scale, both because of high annual production volumes and because of the relatively low rate of their biodegradation [17-19]. In addition, the most common dioctyl phthalate belongs to the $2^{\text {nd }}$ hazard class and has a fairly low biodegradability. Currently, the use of phthalate plasticizers is prohibited in several countries and intensive work is underway to find new alternative plasticizers. For example, the developed plasticizers diisodecylphthalate and diisononylphthal- 
ate are low toxic. However, the most promising area of research in this area is the development of phthalate-free plasticizers and the production of PVC materials based on it, which have good performance and high biodegradation rate in the environment.

One of the modern approaches to the creation of materials destroyed in natural conditions is based on the use of biodegradable additives, which are decomposed by soil microorganisms, which contributes to loosening the structure, reducing the durability of filled polymer materials and, as a result, mechanical destruction of the product [20-22].

The use of natural polymers as biodegradable additives, such as cellulose and starch, does not provide materials with standard reproducible physicomechanical characteristics and satisfactory performance [23-24]. This disadvantage can be avoided by using biodegradable additives of chemical origin. An analysis of the information presented in the literature showed that adipate plasticizers can be used for this purpose, which, in their ability to biodegrade by bacteria, significantly exceed phthalates [25-27]. Adipate plasticizers are also non-toxic compounds and are used in the manufacture of medical devices, children's products, food films, shoes, artificial leather [28-29].

Di (2-ethylhexyl) adipate (DOA) is the standard and most widely used plasticizer of this class. Adipate-based plastisols give polar elastomers good flexibility at low temperatures and high thermal stability.

In this regard, the aim of this work is to develop nontoxic biodegradable PVC compositions with improved deformation and strength properties.

\section{MAIN PART}

The objects of study were PVC films plasticized by a mixture of plasticizers previously prepared by us, namely: dibutoxyethyl phthalate (DBOEP) with a degree of ethoxylation of 1.5 and dibutoxyethyl adipate (DBOEA) with a degree of ethoxylation of 1.5. Physicochemical characteristics of plasticizers are given in [28, 30].
Used PVC composition of the following list: 100 wt. p. PVC; 50 wt. p. plasticizer; 3 wt. p. stabilizer (1.5 parts by weight of calcium stearate and 1.5 parts by weight of zinc stearate). Film samples were obtained on laboratory rollers.

Tensile stress $(\delta)$ was determined according to state standard 11262 and elongation at break $(\varepsilon)$ of PVC films was determined according to state standard 14236 on a tensile testing machine PM-250.

Water absorption $\Delta \mathrm{m}(\%)$ was evaluated according to state standard 4650. For this, the change in the mass of the samples during exposure in distilled water at a temperature of $(23 \pm 2)^{\circ} \mathrm{C}$ for certain time intervals was determined by the formula

$$
\Delta \mathrm{m}=\left[\left(\mathrm{m}-\mathrm{m}_{0}\right) / \mathrm{m}_{0}\right] \cdot 100 \%,
$$

where $\mathrm{m}_{0}$ and $\mathrm{m}-$ the initial mass of the sample and at the time instant $\tau$, respectively.

\section{THE DISCUSSION OF THE RESULTS}

Initially, a study was conducted of the physicomechanical properties of the starting compositions. The test results are presented in table 1 .

One of the laboratory methods for rating the biodegradability of polymeric materials is the change in the mass of PVC samples in water at room temperature (Fig. 1) [31]. In this case, the change in the mass of the films in water is the result of two opposite processes: swelling of the samples and leaching of the components.

The greatest change in the mass of samples of PVC films was observed in the composition containing the largest amount of DBOEA. Similar processes are observed when PVC materials come into contact with the soil, where, under the influence of light and heat, chemical reactions occur in the polymer matrix, leading to the breaking of long chains of polymer molecules. These processes lead to a gradual decrease in the molecular weight of the polymer up to the fragmentation of the material. At the same time, the hydrophilicity of the polymer increases, microcracks

\section{Table 1}

Physicomechanical properties of the initial samples PVC compositions

\begin{tabular}{|c|c|c|c|c|}
\hline \multirow{2}{*}{ № } & \multicolumn{2}{|c|}{ The amount of plasticizer,\% } & \multirow{2}{*}{$\begin{array}{c}\text { Tensile stress, Mpa } \\
\text { (state standard 11262) }\end{array}$} & $\begin{array}{c}\text { Elongation at break, \% } \\
\text { (state standard 11262) }\end{array}$ \\
\cline { 2 - 3 } & DBOEP & DBOEA & 16.5 & 221.0 \\
\hline 1 & 95 & 5 & 16.4 & 224.3 \\
\hline 2 & 90 & 10 & 16.3 & 227.0 \\
\hline 3 & 85 & 15 & 16.2 & 231.6 \\
\hline 4 & 80 & 20 & 16.1 & 237.1 \\
\hline 5 & 75 & 25 & & \\
\hline
\end{tabular}




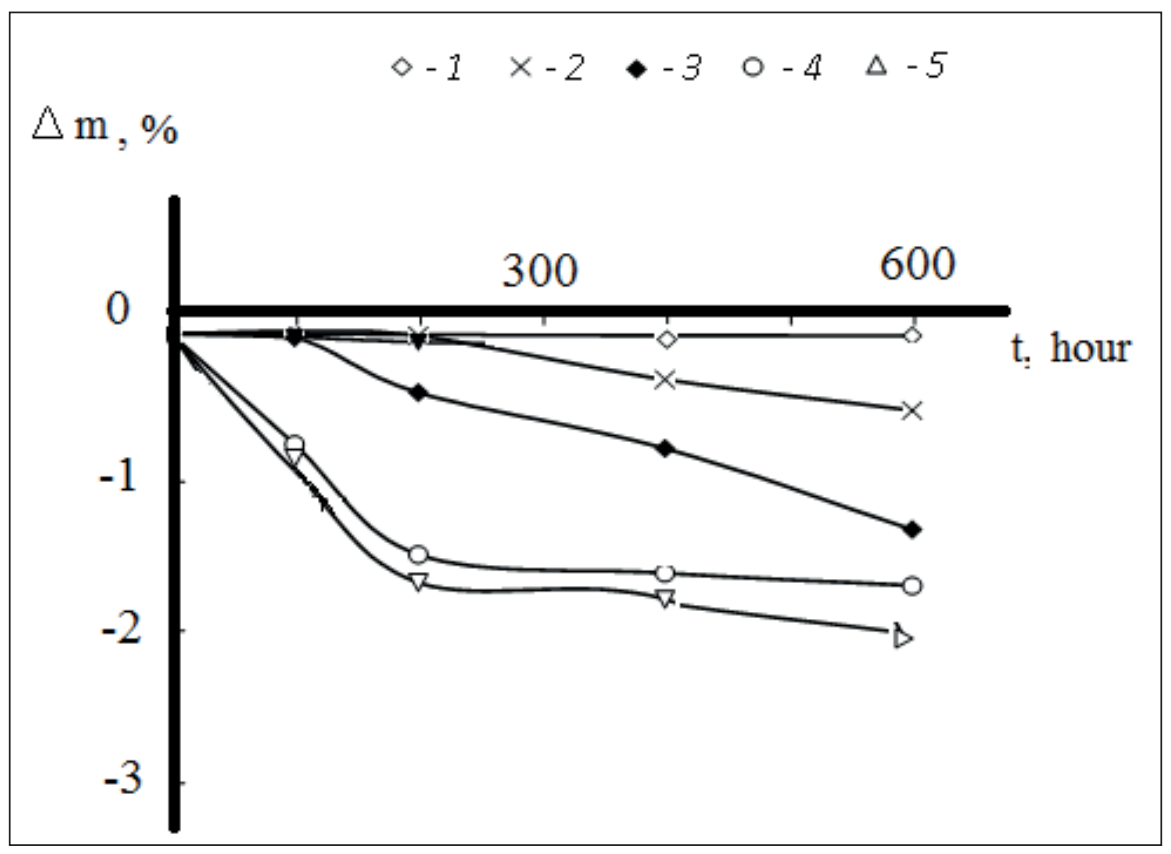

Fig. 1. The change in mass $(\Delta \mathrm{m})$ as a function of time (hour) in water for samples.

The content of DBOEA: $1-5 \% ; 2-10 \% ; 3-15 \% ; 4-20 \% ; 5-25 \%$

form on the surface, and conditions are created to facilitate the penetration into the polymer matrix of microorganisms utilizing short fragile molecules. In the process of life, microorganisms secrete weak acids, which helps to accelerate the decomposition of the material [32-33].

However, this indicator is not the only criterion for assessing the resistance of polymer materials. When contacting filled polymeric materials, such processes as leaching of the filler components, change in its surface, or chemical change in the polymer structure as a result of hydrolysis can occur, which can reduce the adhesion between the filler and the polymer matrix and thereby significantly affect the strength characteristics of the poly- meric material [34-36]. Next, field tests of the obtained samples of PVC films were conducted. To do this, they were placed in the soil. The soil layer is most saturated with microorganisms at a depth of $5-15 \mathrm{~cm}$. Here $1 \mathrm{~g}$ of soil contains up to 108 units of microorganisms. Usually, the more organic matter is contained in the soil, the more microorganisms are in it.

For this reason, we tested biodegradation in the soil while keeping the samples in soil at a depth of $15 \mathrm{~cm}$ for 6 months.

The duration of the period of biodegradation is determined by the film thickness and the activity of the microbiological environment.

\section{Table 2}

Change in tensile stress of samples of PVC compositions during biodegradation (MPa)

\begin{tabular}{|l|c|c|c|c|c|}
\hline \multirow{2}{*}{$\begin{array}{c}\text { Exposure time, } \\
\text { months }\end{array}$} & \multicolumn{5}{|c|}{ The amount of plasticizer, DBOEP / DBOEA, \% } \\
\cline { 2 - 6 } & $\mathbf{9 5 / 5}$ & $\mathbf{9 0 / 1 0}$ & $\mathbf{8 5 / 1 5}$ & $\mathbf{8 0 / 2 0}$ & $\mathbf{7 5 / 2 5}$ \\
\hline initial & 16.5 & 16.4 & 16.3 & 16.2 & 16.1 \\
\hline 1month & 16.4 & 16.3 & 16.2 & 16.1 & 16.0 \\
\hline 2 months & 16.3 & 16.2 & 16.0 & 15.9 & 15.8 \\
\hline 3 months & 16.2 & 16.0 & 15.8 & 15.6 & 15.6 \\
\hline 4 months & 16.0 & 15.8 & 15.5 & 15.3 & 15.2 \\
\hline 5 months & 15.8 & 15.5 & 15.3 & 14.9 & 14.8 \\
\hline 6 months & 15.5 & 15.2 & 14.9 & 14.6 & 14.5 \\
\hline
\end{tabular}




\section{DEVELOPMENT OF NEW POLYMER MATERIALS}

Table 3

Change in elongation at break of samples PVC compositions during biodegradation (\%)

\begin{tabular}{|l|c|c|c|c|c|}
\hline \multirow{2}{*}{$\begin{array}{c}\text { Exposure time, } \\
\text { months }\end{array}$} & \multicolumn{5}{|c|}{ The amount of plasticizer, DBOEP / DBOEA, \% } \\
\cline { 2 - 6 } & $\mathbf{9 5 / 5}$ & $\mathbf{9 0 / 1 0}$ & $\mathbf{8 5 / 1 5}$ & $\mathbf{8 0 / 2 0}$ & $\mathbf{7 5 / 2 5}$ \\
\hline initial & 221.0 & 224.3 & 227.0 & 231.6 & 237.1 \\
\hline 1month & 220.2 & 222.1 & 224.1 & 229.4 & 231.5 \\
\hline 2 months & 219.8 & 219.7 & 221.4 & 226.0 & 227.3 \\
\hline 3 months & 217.8 & 216.2 & 216.9 & 224.0 & 220.0 \\
\hline 4 months & 215.2 & 212.3 & 212.5 & 219.2 & 212.3 \\
\hline 5 months & 213.8 & 210.2 & 208.2 & 214.3 & 204.7 \\
\hline 6 months & 212.2 & 208.2 & 203.8 & 208.2 & 197.0 \\
\hline
\end{tabular}

Biodegradation in soil is a complex process, the speed of which is influenced by the structure and properties of the polymer material and environmental conditions humidity, temperature, acidity of the medium, light, as well as contact with the soil and soil type.

Then, a study was made of the deformation-strength characteristics of the PVC compositions aged in the soil. The results are presented in tables 2,3 .

As a result of biodegradation, the breaking stress and elongation at break of the obtained samples of PVC films are reduced. This suggests that the compiled compositions during aging in the soil become more fragile, since structural changes occur in the polymer matrix, as a result of which the compiled compositions undergo more destruction than the PVC composition that does not contain DBOEA.

Thus, the partial replacement of a phthalate plasticizer (dibutoxyethyl phthalate) with a non-toxic alternative (dibutoxyethyl adipate) allows one to obtain biodegradable thermoplastic PVC compositions. At the same time, their service life and initial physical and mechanical properties are not inferior to industrial plastic compounds based on DOP. This solution is a promising way to reduce the amount of polymer waste and improve the environmental situation.

\section{CONCLUSIONS}

1. The effect of the quantitative replacement of phthalate plasticizers with adipates on the change in breaking stress and elongation at break of samples of PVC compositions was studied. It is shown that when replacing phthalate in the range from 5 to $25 \%$, the physical and mechanical properties remain at the level required by the standards.

2. A study was made of the change in the deformation-strength characteristics of samples of developed biodegradable PVC compositions during field tests in soil. It was found that the most biodegradable is a composition containing 25\% DBOEA.

3. It was revealed that the biological degradation of polymer compositions depends both on the content of adipate plasticizer in the composition and on the test conditions.

\section{REFERENCES}

1. Ul'yanov V.M., Rybkin E.P., Gudkovich A.D., Pishin G.A. Polivinilkhlorid [Polyvinylchloride]. Moscow, Khimiya, 2000. 288 p. (In Russian).

2. Fadina Yu.I. Analiz rossiiskogo rynka polimerov i dal'neishie puti ego razvitiya [Analysis of the Russian polymer market and its further development]. Biznes-obrazovanie v ekonomike znanii = Business Education in the Knowledge Economy. 2017, no. 1, pp. 99-101.

3. Holden G., Kriheldorf H.R., Kuirk R.P. Termoelastoplasty [Thermoplastic Elastomers]. St. Petersburg, Profession, 2011.720 p.

4. Jakoby R. Marketing and sales in the Chemical Industry in Plastics and Rubbers. $2^{\text {nd }}$ ed. New York, Wiley, 2002.177 p.

5. Pakharenko V.A., Pakharenko V.V., Yakovleva R.A. Plastmassy v stroitel'stve [Plastics in Construction]. St. Petersburg, Scientific foundations and technologies, 2010. 358 p. (In Russian). 
6. Mazitova A.K., Aminova G.K., Nafikova R.F., Deberdeev R.Ya. Osnovnye polivinilhloridnye kompozicii stroitel'nogo naznacheniya [Basic polyvinyl chloride compositions for construction purposes]. Ufa, 2013. 130 p. (In Russian).

7. Schiller M. PVC Additives. Composition, properties, application. Germany, Munich, 2014. 400 p.

8. Rahman M., Brazel C.S. The plasticizer market: An assessment of traditional plasticizers and research trends to meet new challenges. Prog. Polym. Sci. 2004, Vol. 29, no. 12, pp. 1223-1248.

9. URL: https://www.plasticisers.org/applications/

10. URL:http://www.mrcplast.ru/

11. Wilkes C.E., Summers J.W., Daniels C.A., Berard M.T. PVC Handbook. Hanser Publications. 2005. 723 p.

12. Godwin A.D. Plasticizers. Applied Plastics Engineering Handbook Elsevier, 2017. 784 p.

13. Chanda M., Roy S.K. Plastics technology handbook. CRC Press, 2006. pp. 1-6.

14. Wickson E.J., Grossman R.F. The development of compositions based on PVC. St.Petersburg, Scientific foundations and technologies, 2009. 608 p. (In Russian).

15. Godwin A.D. Plasticizer selection and phthalate alternatives. Presented at Society of Plastic Engineers Vinyl Division Technical Conference. Vinyltec 2008. Chicago, 2008.

16. Bolton D. Eastman Chemical Webinar Presentation. Suppliers going DEHP-free, it's easier than you think. URL: https:// practicegreenhealth.

17. European Commission Health \& Consumer protection directorate-general, Directorate C-Scientific Opinions, C2. Opinion on Medical Devices Containing DEHP plasticized PVC. Neonates and Other Groups Possibly at Risk from DEHP Toxicity. 2002. Doc.SANCO/SCMPMD/2002/0010:final.

18. Vasnev V.A. Biorazlagaemye polimery [Biodegradable Polymers]. Vysokomolek. Soed. B. = High Molecule. Connection B. 1997, Vol. 39, no. 12, pp. 2073-2086.

19. Gogotov I.N. Biorazlagaemye polimery: svojstva, prakticheskoe ispol'zovanie, utilizaciya [Biodegradable polymers: properties, practical use, disposal]. Ekologiya i promyshlennost' Rossii = Ecology and industry of Russia. 2007, pp. 16-19.

20. Gu J.D., Ford T.E., Mitton D.B., Mitchel R. Microbial degradation and deterioration of Polymeric materials. Review. The Uhlig Corrosion Handbook. Wiley, New York, 2000, pp. 439-460.

21. Shembel N.L., Chebotar A.M., Sagalaev G.V. Napolniteli polimernyh materialov [Fillers of polymeric materials]. Moscow, Knowledge, 1977. pp. 87-91.

22. Sherieva M.L., Shustov G.B., Shetov R.A., Beshtoev B.Z., Kanametova I.K. Issledovanie smesej na osnove kukuruznogo krahmala i polietilena [The study of mixtures based on corn starch and polyethylene]. Materialy II Vserossijskoj nauchno-tekhnicheskoj konferencii «Novye polimernye kompozicionnye materialy» [Materials of the II All-Russian scientific and technical conference "New polymer composite materials"]. Nalchik, 2005, pp. 266-273.

23. Chiellini F., Ferri M., Morelli A., Dipaola L., Latini G. Perspectives on alternatives to phthalate plasticized poly(vinyl chloride) in medical devices applications. Prog. Polym. Sci. 2013, Vol. 38, no. 7, pp. 1067-1088.

24. Vieira M.G.A., Silva M.A.D., Santos L.O., Beppu M.M. Natural-based plasticizers and biopolymer films: A review. Eur. Polym. J. 2011, Vol. 47, pp. 254-263.

25. Vijayendran B.R., Benecke H., Elhard J.D., McGinniss V.D., Ferris K.F. Environmentally Friendly Plasticizers for Polyvinyl Chloride (PVC). Resins Antec, Dallas, Texas, 2001, 604 p.

26. Vikhareva I.N., Builova E.A., Gatiyatullina D.R., Arslanov V.R., Gilem'yanov D.A., Mazitova A.K. Sintez i svoistva slozhnykh efirov adipinovoi kisloty [Synthesis and properties of adipic acid esters]. Bashkirskii khimicheskii zhurnal = Bashkir chemical journal. 2019, Vol. 26, no. 2, pp. 33-36.

27. Mazitova A.K., Vikhareva I.N., Aminova G.K., Timofeev A.A., Builova E.A., Distanov R.Sh. Issledovanie vliyaniya kolichestva dobavok na svoistva efirov adipinovoi kisloty [Investigation of the effect of the amount of additives on the properties of adipic acid esters]. Nanotechnologies in construction. 2019, Vol. 11, no. 4, pp. 437-446.

28. Maskova A.R., Aminova G.K., Rolnik L.Z., Faizullina G.F., Mazitova A.K. Oxyalkylated alcohols phthalates. Nanotechnologies in Construction. 2019, Vol. 11, no. 1, pp. 52-71. DOI: 10.15828/2075-8545-2019-11-1-52-71.

29. Ermolovich O.A., Makarevich A.V., Goncharova E.P., Vlasova G.M. Methods for Analyzing of Biodegrability of Polymeric Materials. Biotechnology in Russia. 2005, № 4, pp. 47-54.

30. Shtilman M.I. Biodegradaciya polimerov [Biodegradation of polymers]. Zhurnal sibirskogo federal'nogo universiteta. Seriya: biologiya $=$ Journal of the Siberian Federal University. Series: biology. 2015, Vol. 8, no. 2, pp. 113-130.

31. Bakshitsky M.N. Dlitel'naya prochnost' polimerov [Long lasting polymer strength]. Moscow, Chemistry, 1978.312 p. (In Russian).

32. Orekhov D.A., Vlasova G.M., Makarevich A.V., Pinchuk L.S. Biorazlagaemye plenki na osnove termoplastov [Biodegradable films based on thermoplastics]. Reports of the National Academy of Sciences of Belarus. 2000, Vol. 44, no. 6, pp. 100-103. 
33. Suvorova A.I. Biorazlagaemye sistemy: termodinamika, reologicheskie svojstva i biokorroziya [Biodegradable systems: thermodynamics, rheological properties and biocorrosion]. Vysokomolekulyarnye soedineniya = High-molecular compounds. 2008, Vol. 50, no. 7, pp. 1162-1171.

34. Rybkina S.P., Pakharenko V. A., Shostak T. S., Pakharenko V.V. Osnovnye napravleniya v oblasti sozdaniya biorazlagaemyh termoplastov [The main directions in the field of creating biodegradable thermoplastics]. Plasticheskie massy $=$ Plastics. 2008, no. 10 , pp. $47-54$.

\section{INFORMATION ABOUT THE AUTHORS}

Aliya K. Mazitova, Dr. Sci. (Chem.), Professor, Ufa State Petroleum Technological University; Mendeleev St., 195, Ufa, Bashkortostan Republic, Russia, 450080; elenaasf@yandex.ru;

Irina N. Vikhareva, Assistant, Ufa State Petroleum Technological University; Mendeleev St., 195, Ufa, Bashkortostan Republic, Russia, 450080; irina.vikhareva2009@yandex.ru;

Albina R. Maskova, Cand. Sci. (Eng.), Associate Professor, Ufa State Petroleum Technological University; Mendeleev St., 195, Ufa, Bashkortostan Republic, Russia, 450080; asunasf@mail.ru;

Natalia B. Gareeva, Dr. Sci. (Eng.), Professor, Ufa State Petroleum Technological University; Mendeleev St., 195, Ufa, Bashkortostan Republic, Russia, 450080; natagon56@mail.ru;

Irek R. Shaikhullin, Cand. Sci. (Eng.), Associate Professor, Ufa State Petroleum Technological University, Mendeleev St., 195, Ufa, Bashkortostan Republic, Russia, 450080; adtsp@yandex.ru 